\title{
Policy Brief of Common Grazing Land Management in the Northern Highland Ethiopia: Review
}

\author{
Yeshiwas Tilahun*1 \\ Amhara Agricultural Research Institute, Ethiopia, Socio-Economics Research Division, \\ P.O.BOX: Bahir Dar ,27
}

\begin{abstract}
Ethiopia is the highest with livestock population in Africa and its growth is increasing with population growth. Small holder farmers' livelihood and the country national income is depending on livestock and crop production. In the livestock sector, free grazing is the major feeding livestock system and communal grazing land is the main feeding source. Poor communal grazing land management leads overgrazing of communal grazing land followed by environmental degradation in particular soil erosion. The government realized the problems but the policy effectiveness on communal grazing land is not reviewed well. This paper aimed to review common grazing land management and the policy and its effectiveness in the northern highland of Ethiopia. The livestock population is increasing dramatically so that it is becoming high threat for common grazing land. Livestock policy was adopted in Ethiopia but the implementation is weak due to low enforcement mechanism for common grazing management. To overcome the common grazing land management problem in the near time, disincentive policies like tax per head, need to encourage private investment, increase livestock productivity and need to adopt optimum allocation livestock stock rate.
\end{abstract}

DOI: $10.7176 /$ JRDM/81-02

Publication date: December $31^{\text {st }} 2021$

\section{Introduction}

Ethiopia is the first ranked country in Africa in its livestock population which is estimated to be about 59.5 cattle million, 30.70 million sheep, 30.20 million goat 2.16 million horses, 8.44 million donkeys, 0.41 million mules, and about 1.21 million camels (CSA, 2017). The livestock population is growing fast with human population growth. The livestock sector has great role for smallholder livelihood income and country national income. The sector contribute contributes 35\% of the country GDP (Shapiro et al, 2017). Mixed farming system (both crop farming and livestock rearing) is the common agricultural production system in the Northern Highland Ethiopia. In the livestock sector, free grazing is the major feeding livestock system and communal grazing land is the main feeding source (Alemu Gashe and Awoke Kassa, 2018).

In Ethiopia rural farmers' livelihood is highly depend up on livestock. Any rural farmers whose age reaches married needs to have livestock to leading his/her life. Thus, rural population growth is one of the factors for increasing of livestock population. Though livestock is the fundamental contributor for farmers' livelihood and national GDP, the livestock is becoming high pressure on grazing land. This leads overgrazing of communal grazing land followed by environmental degradation in particular soil erosion.

Mixed farming system is currently computes with livestock production in the highland areas in Ethiopia. Private grazing land are going to be shifted to crop cultivation but livestock population and its impact on communal grazing land is not considered. Absence of strong enforcement mechanisms and institutions on land use leads to overexploitation of communal grazing land (Tom Kimball, 2011)

The government realized the problems arise on communal grazing land and took measurements like restricted grazing and area closure but the policy effectiveness with the theory of natural resource management is not reviewed well. Thus, the objective of this paper was to review common grazing land management and the policy and its effectiveness in the northern highland of Ethiopia.

\section{Livestock production and common grazing land}

\subsection{Overview of livestock production system in Ethiopia}

Livestock production system is broadly classified in to two systems; Highland crop-livestock mixed farming system \& lowland pastoral and agro-pastoral production system. In the highland area, farming is defined as crop and livestock production in which livestock and crop are inseparable livelihood source of farmers (MOARD, 2007). The main source of livestock feed is natural pasture. The crop residues are other sources but adopting of technologies like chemical treatment of feeds is not practiced. Farmers do not have skill of conserving feed like silage (Alemu Gashe and Awoke Kassa, 2018).With limited grazing land the livestock population trend is increasing with positive linear trend(Nega et al ,2003).Common grazing land is gradually converted to farm land(MOARD, 2007). 


\subsection{Communal grazing land management system}

Poor production of pasture lands and large herd size on small grazing lands caused overgrazing of natural pasturelands resulting in serious land degradation. Grazing lands which were main source of natural pasture are being deteriorated due to high population pressure, land degradation and conversion of grazing lands into arable lands (Nigus, 2017). In many parts of Ethiopia the common livestock feeding system is free grazing of common pasture. This open access grazing land is resulting higher pressure on grazing land (Benin, S. and Pender, J., 2002). To minimize this problem in the Northern Highlands, there was collective action of communal grazing land management practices by restricting the grazing area but this practice was triggered the pressure on unrestricted grazing areas. Livestock population with rapid population growth contributes for communal grazing land degradation and there are no strong enforcing institutions to manage grazing land so that people access freely (Nega et al, 2003).Over-sowing and rotational grazing, supply of improved forage, cut and currying system, and stall feeding are among measurements to develop common grazing lands(Shapiro et al, 2017). The government is undertaking area closure and protecting it from livestock contact with deploying of the livestock on the remaining open grazing land(Asres, H.G., 2012,Alemu Gashe and Awoke Kassa, 2018)

\subsection{Open access grazing land}

In open access case, livestock producers could not exclude others' livestock in the community. As a result, profit maximization and available grass biomass is not depending on the grazing level of previous season. The grass biomass of the next season depends on the grazing level of the current users or livestock. Moreover, in open access grazing land there is no owner who collects rent and livestock producers behave as the price of grass biomass is zero. Unlike optimally managed grazing land, open access grazing land has no marginal user costs. Farmers who has higher herd size are more beneficiary than those who has less /no livestock size (Hadush, M., 2017). Since there is no any restriction, in the long run marginal profit of livestock owners' profit is going to zero as harvest increases implied over exploitation.

\section{Empirical data evidence}

Comparing the livestock population growth with area of grazing land we can realized that the biomass of grass is going to be decreased.

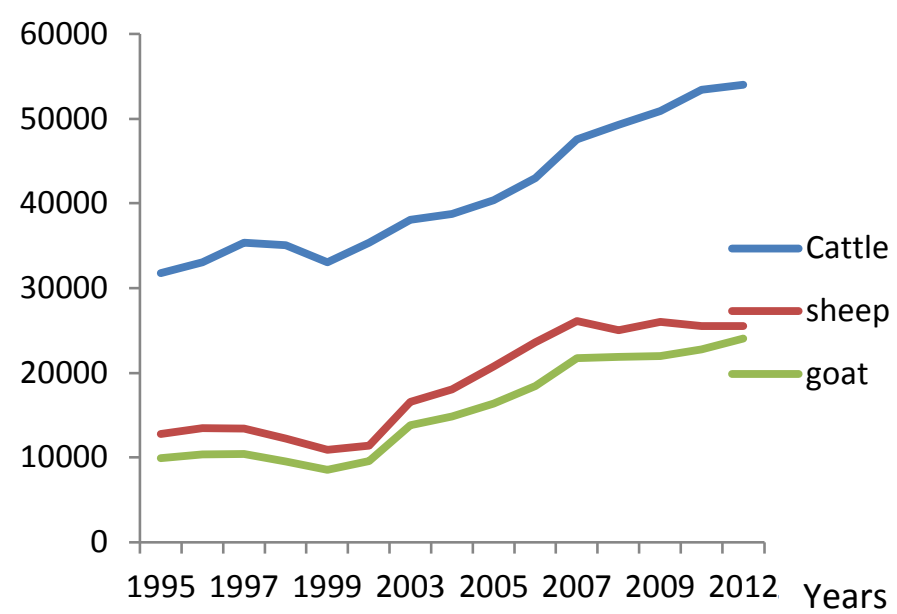

Figure1: Livestock population in 1000 head

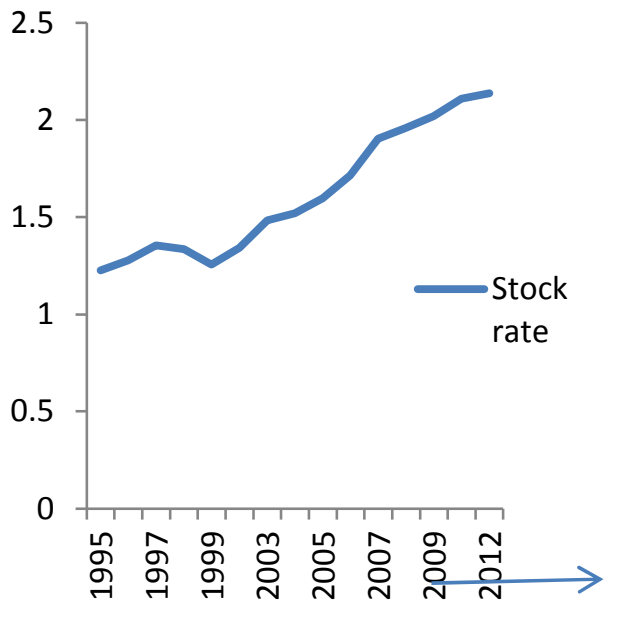

Figure2: Stock rate per ha.

Source: Samson Leta and Frehiwot Mesele (2014) and FAO STAT 1995-2012

\section{Current communal grazing land management policy}

The first government attention for livestock sector was started in the 1930s when the policy objective was addressing the rising milk demand in the city. With the current government regime, the livestock revolution policy was planned with the objective of double increase in milk and meat production. The issue of common grazing management was not considered in the policy frame work for long time(MOARD, 2007).

Though there are many policies related to livestock sector, the land administration and use policy is the one which is more specific to common grazing land. The first rural land use and administration proclamation (89/1977) vested farmers the right to free and non-time-bound access of rural land(MOARD, 2007).This unrestricted land rights brought private benefit maximization without considering environment optimization.

The land policy concerns on proper use of resources and the government advocates the sustainable use of land. Improving animal food production, better land use management and agro-forestry programs are potential 
basis for animal feed production. Farmers need to decrease the dependence on open grazing land by growing improved growing grass. It is planned to gradually stop open grazing practices and to integrate with homestead pasture development, improving grazing land and developing pasture crops for zero grazing practices. To improve animal health services focus will be on prevention through provision of extensive vaccination services, training of animal health specialists, and expanding the institutions, including mobile service provision (MoA and ILRI. 2013).

Recently area closure, restricted grazing land, rotational grazing land, cut and carry system and stall feeding are getting policy concern to manage communal grazing land in northern highland Ethiopia (Alemu Gashe and Awoke Kassa, 2018),Asres, H.G., 2012, Gebremedhin et al,2004). Whatever policy instruments applied the objective is increasing or recovering grass biomass by decreasing harvest of the grass by livestock on a given grazing land.

As area closed, restricted, rotation or using stall feeding is decreasing effort on common grazing land to feed livestock so that the grazing decrease and grass biomass increase or regenerate.

\subsection{Evaluating the effectiveness of policy and its implementation}

Collective action, through restrictions and community rules, can play a significant role in sustainable grazing land management. Restricting access and use can reduce degradation of the resource by eliminating overexploitation and, therefore, improve availability and quality of forage on restricted areas. On the other hand, in restricting grazing area there is tendency to shift the pressure on other unrestricted grazing areas and be overexploited (Benin, S. and Pender, J., 2002).

Restricted use of grazing lands tends to be maintained once it is established and collective action likely to be effective in area where there is intermediate population size to share costs associated with collective action (Gebremedhin et al, 2004).

In northern highland Ethiopia, the establishment of area closure is the best and effective policy measure to protect further grazing land degradation. Exclusion of livestock grazing from selected areas, as an important policy instrument to allow the recovery degraded vegetation provided that they are properly protected and managed. The strategy of area enclosure coupled with community based resource management practice is a key factor for the observed restoration of natural vegetation cover (Gidey, T.G. and Van der Veen, A., 2014).

Though it is the recent policy action, the trial of stall feeding of livestock is effective in Ethiopia. Stall feeding is less attractive to those farmers with more herd size and less crop residue (Hadush, M., 2017) but it is both economically and ecologically viable (Beshir, 2014)

The policy of area enclosures in Ethiopia is acting exclusion of livestock grazing and human interference from selected areas. This policy instrument is effective in recovering the degraded grass (Gidey, T.G. and Van der Veen, A., 2014). Though the above policies are effective, the livestock holding size is not considered. Those livestock which are prohibited from enclosure area are grazing the other part of communal land. Farmers harvest higher biomasses of grass on protect grazing land but unprotected grazing land carrying capacity is becoming lower than before. As a result communal grass over -exploitation and then soil degradation become sever.

\section{Conclusion and recommendation}

The livestock population is increasing dramatically so that it is becoming high common grazing land threat. The government has no strong concern on livestock population rather it is becoming busy in fulfilling livestock feed. Keeping the government effort on this side, to overcome the problem in the near time, disincentive policies like tax per head should be introduced to decrease livestock population and then overgrazing.

Limited alternatives of livestock feed resources is one of the factors for overexploitations of common grazing land areas. Improved fodder production and the investment on forage sector are so low that private investments and trade need to be encouraged.

In Ethiopia farmers keep low productive local cattle. They may receive the benefit of 5 cows from one improved cow. Replacement of local stock with fewer improved breeds need to be considered so as to decrease the degraded land pressure (grass).

In most areas huge number of livestock invaded common grazing land without any restriction. Livestock policy was adopted in Ethiopia but the implementation is weak due to low enforcement mechanism for common grazing management. Collective action for common grazing land management is one of the practices exercised in the country. Partial restricting common grazing land management system brought improvements for restricted one but create high pressure on unrestricted one. When management practices were applied, the livestock population pressure on unrestricted resource was forgotten. Thus, optimum allocation livestock stock rate need to be considered.

\section{References}

Alemu Gashe and Awoke Kassa. (2018). Evaluation of Grazing Land Condition in Gozamen District , East Gojjam Zone , Evaluation of Grazing Land Condition in Gozamen District , East Gojjam Zone , Amhara Regional 
State , Ethiopia. International Jouranl of Scientific Research in Environmental Science and Toxicology, (March).

Asres, H.G., 2012. Effect of exclosure on environment and its socio economic contributions to local people: in the case study of halla exclosure, Tigray, Ethiopia (Master's thesis, Norwegian University of Life Sciences, Ås).

Benin, S. and Pender, J., 2002.Community management of grazing lands and impact on environmental degradation in the Ethiopian highlands. IASCP paper

Beshir, H., 2014. Factors affecting the adoption and intensity of use of improved forages in North East Highlands of Ethiopia. American Journal of Experimental Agriculture, 4(1), p.12.

CSA. (2017). Livestock and Livestock Characteristics (Private Peasant Holdings) (Vol. II). Addis Ababa,Ethiopia.

Gebremedhin, B., Pender, J. and Tesfay, G., 2004. Collective action for grazing land management in croplivestock mixed systems in the highlands of northern Ethiopia. Agricultural Systems, 82(3), pp.273-290.

Gidey, T.G. and Van der Veen, A., 2014. The effect of enclosures in rehabilitating degraded vegetation: a case of Enderta district, northern Ethiopia. Forest research, 3(4).

Hadush, M., 2017. EXPLORING FARMERS'SEASONAL AND FULL YEAR ADOPTION OF STALL FEEDING OF LIVESTOCK IN TIGRAI REGION, ETHIOPIA. Economics of Agriculture, 64(3), pp.919944.

Mo AR. Livestock development master plan study phase I report-data collection and analysis, volume Napiculture, ministry of agriculture and rural development (MoARD). Addis Ababa, Ethiopia. 2007.

MoA and ILRI. 2013. Review of past policies and strategies for livestock in Ethiopia. Addis Ababa, Ethiopia: Ministry of Agriculture and International Livestock Research Institute

Nega, B., Adenew, B. and Gebre Sellasie, S., 2003. Current land policy issues in Ethiopia. Land Reform, Land Settlement, and Cooperatives, 11(3), pp.103-24

Nigus, A. (2017). Pasture Management and Improvement Strategies in Ethiopia, 7(1), 69-78.

Shapiro, B.I., Gebru, G., Desta, S., Negassa, A., Nigussie, K., Gezahegn, A. and Henok, M., 2017. Ethiopia livestock sector analysis: A 15 year livestock sector strategy

Tom Kimball. (2011). Chapter 3 Livestock Production Systems and their Environmental Implications in Ethiopia. Addis Ababa,Ethiopia.

http://web.colby.edu/eastafricaupdate/files/2012/02/Environmental-Policy-Review-2011_Chapter3_color_small.pdf 